\title{
SURFACE ELECTROMYOGRAPHY ASSESSMENT OF MUSCLE ACTIVATION PATTERNS WHILE SITTING DOWN IN YOUNG HEALTHY WOMEN AND PATIENTS WITH ANKYLOSING SPONDYLITIS
}

\author{
Amr Mohamed Zaki Zaatar, Jaroslav Opavský, Petr Uhlír
}

Faculty of Physical Culture, Palacký University, Olomouc, Czech Republic

Submitted in January, 2010

BACKGROUND: Muscle activation patterns depend on many factors. Surface electromyography (SEMG) can reveal these patterns in subjects of different ages and health states. We studied patterns of muscle activation in two groups of subjects - healthy young women (as a control group) and patients with ankylosing spondylitis.

OBJECTIVE: The aim of this study was to register and compare muscle activation patterns while sitting down in these two groups in four situations with different positions of the lower and upper limbs.

METHODS: Muscle activity was registered with the use of 8 channel surface polyelectromyography (Noraxon-Myosystem 1400A). We tested the following muscles bilaterally while the subjects were sitting down (tibialis anterior muscle, medial head of the gastrocnemius muscle, gluteus maximus muscle, erectores spinae muscles). The onset of each individual muscle's activity was determined by calculating the sum of the mean value of the SEMG baseline plus $10 \%$ of the maximum value of amplitude (peak).

RESULTS: It was registered that the medial head of the gastrocnemius muscle and/or erectores spinae muscles were activated as the first ones in both groups of the subjects under study in most of the studied postural situations. We registered differences in timing (sequence of muscle activation) among various studied body and limb positions (P-, P+, PD-, and PN-). A great degree of variability in the sequence of muscle activation was revealed, depending on the positions of the upper and lower limbs.

CONCLUSIONS: We did not find any unique patterns of muscle activation in either of the two groups under study.

Keywords: Poly-EMG, sitting down, healthy young women, ankylosing spondylitis.

\section{INTRODUCTION}

Muscle activation patterns depend on many factors, such as neurophysiological and biomechanical ones, types of movement, and on many others. Patients with ankylosing spondylitis (AS) are limited in the range of motion of the spinal column for its progressive structural changes and for pain. These factors can play a role in the modification of muscle activation patterns in these patients. Polyelectromyography is an experimental technique concerned with the recording and analysis of myoelectric signals (Konrad, 2005), mainly during the process of an active movement. Sequences of muscle activation and/or patterns of muscle activation were assessed in our study with the use of surface electromyography (SEMG). We studied patterns of muscle activation in two groups of subjects - healthy young women (as a control group) and patients with ankylosing spondylitis. Patterns of muscle activation depend on the primary position of the foot while standing up (Trew \& Everett, 1997). Similarly the position of a foot can influence the pattern of muscle activation while sitting down. Véle (1997) presents movement as such as an individual process, which depends on sensorimotor experience and it can be variable in individual human subjects. Therefore, sitting down can be variable and it differs between healthy young women (as controls without any restriction of their spinal range of motion) and patients with ankylosing spondylitis while sitting down.

The main aim of this study was to register and compare muscle activation patterns while sitting down with the use of SEMG in the above mentioned two groups of subjects under study, in four situations with various positions of the lower and upper limbs.

\section{MATERIAL AND METHODS}

The whole group of subjects under study included 28 subjects, divided into two groups of different age: 1) 12 healthy younger women as a control group (C) (with a mean age of 21.6 years); 2) and 16 patients with ankylosing spondylitis - 11 men and 5 women (AS there was a mean age of 51.8 years). Muscle activity was registered with the use of an 8-channel SEMG (Noraxon - Myosystem 1400A, with a sampling frequency of $1000 \mathrm{~Hz}$, while the resistance of the SEMG recorder 
was $>10 \mathrm{M} \Omega$ ). A test of laterality was used for the determination of the dominant lower limb (Wai-Hang, 2004). We tested the following muscles bilaterally while sitting down (1 as one of their daily activities) (Hof et al., 2002; William et al., 2002; Noraxon-Myosystem 1400). Using the programme MyoResearch XP Master Version 1.03.05. We chose these muscles for observing their postural reaction while sitting down, which is one of their daily performed motor tasks. We studied four muscles at a different level, which play an important role while sitting down:

- The tibialis anterior muscle (TA): the ventral side of the lower leg, just lateral from the tibia.

- The medial head of the gastrocnemius muscle (MG): the middle of the muscle bulge.

- The gluteus maximus muscle (GM): on s line between the greater trochanter bone and the sacrum.

- The erectores spinae muscles (ES): at the level of $\mathrm{L}_{2}-\mathrm{L}_{3}$.

Two electrodes $(\mathrm{Ag} / \mathrm{AgCl})$ were attached to every muscle, the distance between electrodes was $1 \mathrm{~cm}$ and the size of each electrode was $24 \mathrm{~mm}$.

The onset of each individual muscle's activity was determined by calculating the sum of the mean value of the EMG baseline activity of each muscle at rest plus $10 \%$ of the maximum amplitude value of the same muscle $($ peak $)($ threshold $=$ mean $+10 \%$ peak $)($ De Luca, 1993; Smékal et al., 2005). The falling down of each individual muscle was assessed analogically. For recognizing the pattern of muscle activation we detected the first muscle's activation and than a sequence of the activation of the other ones. In situations with a time difference between the onset of muscle activation of less than $10 \mathrm{~ms}$, it was considered to be synchronous onset of muscle activity.

We studied the subjects with various positions of the lower and upper limbs:

- Standing with feet at hip width apart, the hands were freely suspended and sitting down was performed without pushing with the hands on the anterior aspect of the thigh (the hands were hanging freely): $\mathrm{P}-$.

- Standing with the feet hip width apart, their hands were freely suspended and sitting down was performed while pushing with the hands on the anterior aspect of the thigh: $\mathrm{P}+$.

- Standing with the feet hip width apart, the hands were freely suspended and sitting down was performed without pushing with the hands on the anterior aspect of the thigh with the dominant leg forward (the hands were hanging freely): PD-.

- Standing with the feet hip width apart, the hands were freely suspended and sitting down was performed without pushing with the hands on the an- terior aspect of the thigh with the non-dominant leg forward (the hands were freely hanging): PN-.

\section{RESULTS}

In the situation in which they were sitting down with their feet hip width apart without pushing with their hands on the anterior aspect of the thigh ( $\mathrm{P}-)$, the medial head of the gastrocnemius muscle was activated as the first one, and the erectores spinae muscles were activated as the second muscles in a group of healthy young women on the dominant lower limb. On the non dominant leg, erectores spinae muscles were activated as the first ones, followed by the gastrocnemius muscle. Activation of the tibialis anterior muscle and gluteus maximus muscle followed it with a relatively greater delay (Fig. 1).

A similar pattern of muscle activation (sequence of activation - timing) was revealed in patients with ankylosing spondylitis in both lower limbs. The medial head of the gastrocnemius muscle and the erectores spinae muscles were activated as the first ones, and the tibialis anterior muscle and the gluteus maximus muscle were activated afterward with a delay (Fig. 1).

The early activation of the medial head of the gastrocnemius muscle and the erectores spinae muscles was revealed in a high percentage of the subjects from both groups under study with limbs in the $\mathrm{P}$ - position. A late activation of the gluteus maximus muscle was registered in a high percentage of the subjects from both groups with the same position of their limbs (P-). A tendency to a later activation of the tibialis anterior muscle was detected in a group of healthy young women.

The gluteus maximus muscle and erector spinae muscles were activated as the first ones on the dominant lower limb in healthy young women (Fig. 2) with the limbs in the following position: standing with their feet hip width apart, while pushing with their hands on the anterior aspect of the thigh (limb position $\mathrm{P}+$ ).

Muscle activation in patients with ankylosing spondylitis with their limbs in the following position: while pushing with their hands $(\mathrm{P}+)$ was similar to the sequence of activation in these patients with their limbs in the position without pushing on them with their hands (P-) (Fig. 2).

A higher percentage of an early activation of the erector spinae muscles was revealed in both groups of subjects under study in limb position $\mathrm{P}+$ in comparison with P-.

A higher percentage of the late activation of the tibialis anterior muscle was registered in both groups of subjects under study in limb position $\mathrm{P}+$ than in position $\mathrm{P}$-. 
Fig. 1

Standing with feet hip width apart without pushing with the hands on the anterior aspect of thigh (P-), patterns of muscle activation (according to the order of the onset of muscle activity, expressed in per cent)
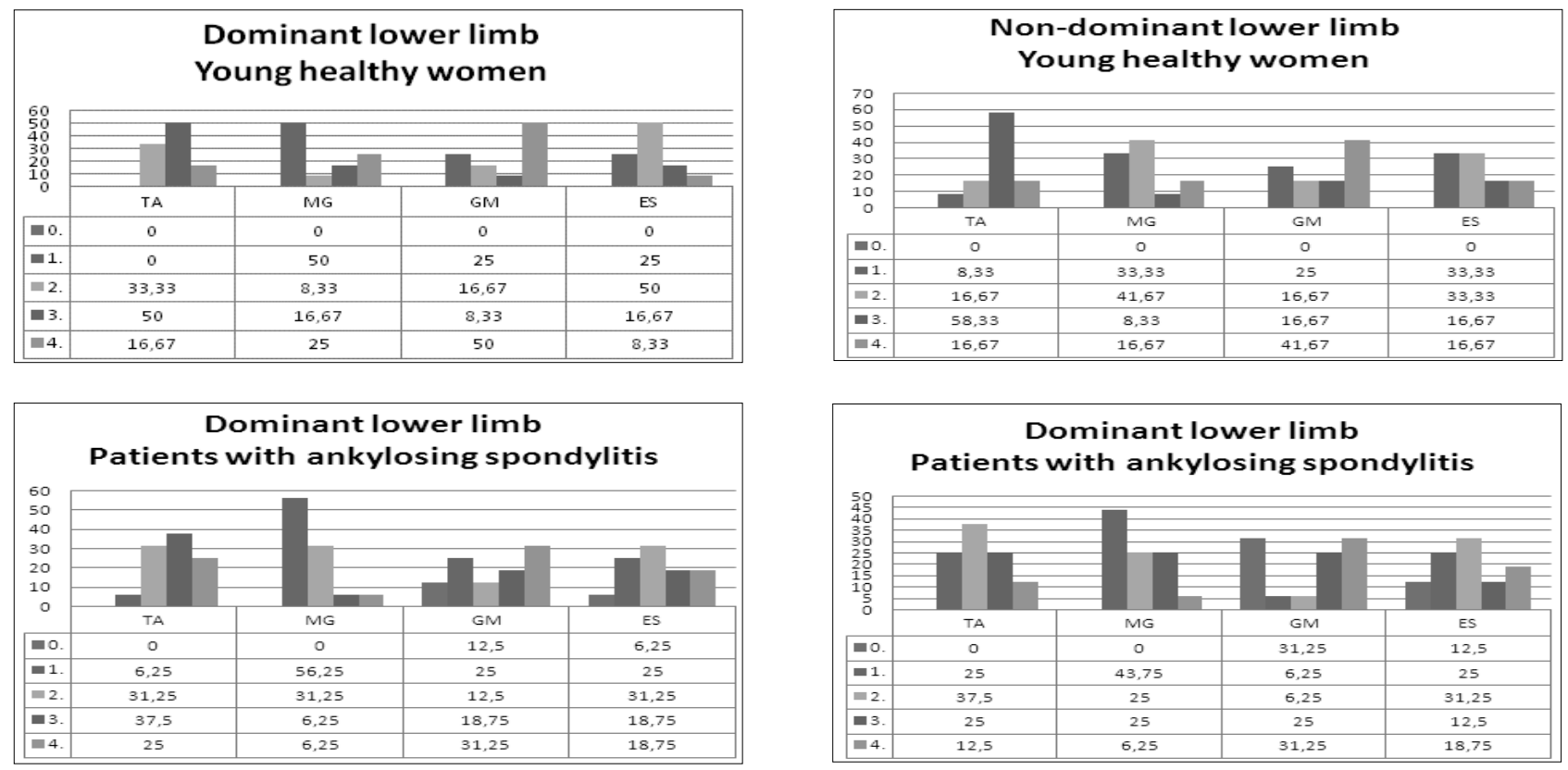

Legend: TA - tibialis anterior muscle, MG - medial head of the gastrocnemius muscle, GM - gluteus maximus muscle, ES - erectores spinae muscles, 1., 2., 3., 4. - an order of the muscle activation (timing), 0 - without EMG activity

Fig. 2

Standing with feet hip width apart with pushing with the hands on the anterior aspect of the thigh $(\mathrm{P}+)$, patterns of muscle activation (according to the order of the onset of muscle activity, expressed in per cent)
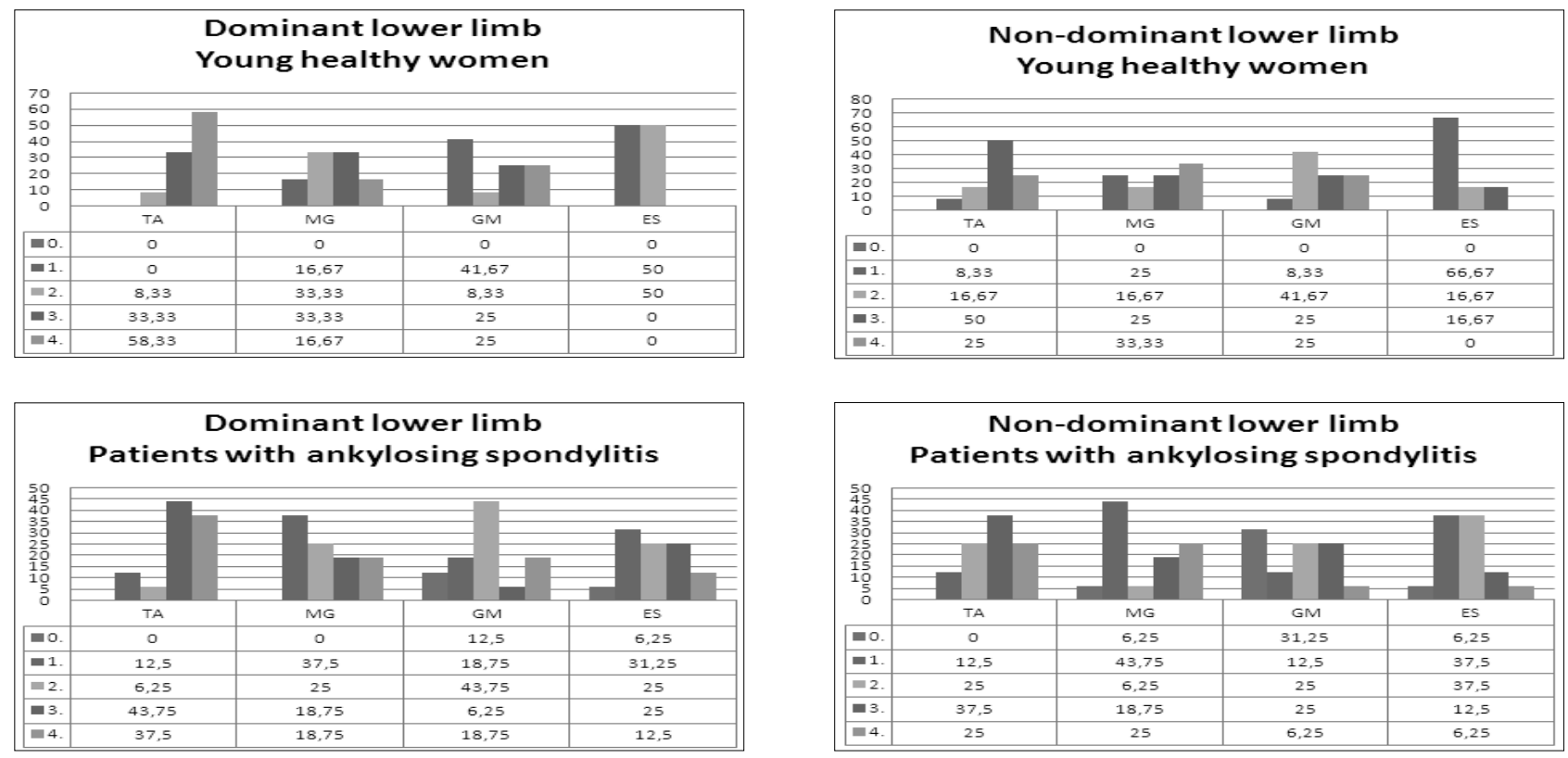

Legend: TA - tibialis anterior muscle, MG - medial head of the gastrocnemius muscle, GM - gluteus maximus muscle, ES - erectores spinae muscles, 1., 2., 3., 4. - an order of the muscle activation (timing), 0 - without EMG activity 
Timing (the sequence of activation) of the medial head of the gastrocnemius muscle revealed a great variability in both groups.

A high percentage of the early activation of the erector spinae muscles was shown in both groups of subjects under study in limb position PD-, more frequently in healthy young women than in patients. The order of the activation of the gluteus maximus muscle was variable in both groups. In a high percentage of healthy young women a later activation of the tibialis anterior muscle than in patients with ankylosing spondylitis was revealed.

Early activation of the erector spinae muscles was revealed in both groups under study in a standing position, with feet hip width apart without pushing with the hands on the anterior aspect of the thigh, with the non-dominant leg forward (PN-). It was registered more frequently in a group of healthy women in comparison with patients with ankylosing spondylitis. A late activation of the medial head of the gastrocnemius muscle was registered in a group of healthy young women in the same limb position (PN-). The sequence of muscle activation was variable in our patient's group.

The duration of the sitting down process lasted longer in patients with ankylosing spondylitis than in healthy controls in all examined situations (TABLE 1).

\section{DISCUSSION}

Various positions of the lower and upper limbs influenced muscle activation patterns (timing, sequence of muscle activation) while sitting down. It was regis- tered that the medial head of the gastrocnemius muscle and/or the erector spinae muscles were activated as the first ones in both groups of the subjects under study in most of the studied postural situations (with different limb positions). Various indices of the SEMG should be used for a registration of muscle activation while sitting down. We used a moment of the onset of muscle activity; other authors used a maximal voluntary contraction (MVC) (Ferrante et al., 2005). The medial head of the gastrocnemius and gluteus maximus muscles always showed a higher MVC while standing up than while sitting down (Ferrante et al., 2005). We could not compare our results fully with the results of other studies due to differences in the assessment of the moment of the onset of muscle activation used by other authors. Heinonen et al. (2005) found that the activity of the erector spinae muscles was significantly greater in patients with AS than in control subjects. Hase et al. (2004) found that during an initial phase of sitting down, and a decreased activation of the erectores spinae muscles and an increased activation of the tibialis anterior muscle and gastrocnemius muscle were registered. Sitting down requires a high degree of postural control and it is without visual control. The tibialis anterior muscle probable works as a brake during the last phase of sitting down. The sequence of muscle activation was used in coordination with a proximodistal strategy in young women.

We registered differences in timing (sequence of muscle activation) among different studied body and limb positions ( $\mathrm{P}-, \mathrm{P}+, \mathrm{PD}-$, and $\mathrm{PN}-$ ). We were able to observe a great variability in the sequence of muscle activation depending on the positions of the upper and

\section{TABLE 1}

Mean duration (in seconds) of muscle activation while sitting down in young healthy women (control group - C) and in patients with ankylosing spondylitis (AS)

\begin{tabular}{|l|c|c|c|c|c|c|c|c|}
\hline \multirow{2}{*}{ Duration - s } & \multicolumn{4}{|c|}{ DOMINANT LOWER LIMB } & \multicolumn{5}{c|}{ NON-DOMINANT LOWER LIMB } \\
\cline { 2 - 10 } & TA & MG & GM & ES & TA & MG & GM & ES \\
\hline C PD- & 1.38 & 1.98 & 1.83 & 1.69 & 1.61 & 1.93 & 1.83 & 1.66 \\
\hline AS PD- & 2.25 & 2.74 & 2.53 & 2.62 & 2.76 & 2.79 & 2.37 & 2.59 \\
\hline C PN- & 1.65 & 1.53 & 1.77 & 1.67 & 1.57 & 1.89 & 1.78 & 1.59 \\
\hline AS PN- & 3.13 & 2.90 & 2.67 & 2.64 & 2.55 & 2.56 & 1.92 & 2.81 \\
\hline C P+ & 1.84 & 1.92 & 2.31 & 1.98 & 1.69 & 1.94 & 1.94 & 1.78 \\
\hline AS P+ & 3.18 & 3.10 & 2.44 & 2.84 & 2.90 & 2.76 & 2.23 & 3.01 \\
\hline C P- & 2.16 & 2.01 & 1.66 & 1.87 & 1.98 & 2.09 & 2.56 & 1.77 \\
\hline AS P- & 2.92 & 2.80 & 2.69 & 2.85 & 3.16 & 2.75 & 2.73 & 3.01 \\
\hline
\end{tabular}

Legend: TA - tibialis anterior muscle; MG - medial head of the gastrocnemius muscle; GM - gluteus maximus muscle; ES - erectores spinae muscles; C - controls (young healthy women); AS - patients with ankylosing spondylitis; PD- - standing with feet hip width apart without pushing with the hands on the anterior aspect of the thigh, dominant leg forward; PN- - standing with feet hip width apart without pushing with the hands on the anterior aspect of the thigh, non-dominant leg forward; $\mathrm{P}+$ - standing with feet hip width apart while pushing with the hands on the anterior aspect of the thigh; P- - standing with feet hip width apart without pushing with the hands on the anterior aspect of the thigh 
lower limbs. No unique or typical patterns of muscle activation were registered in both of the groups under study while sitting down.

\section{CONCLUSION}

Multi channel surface electromyography provided detailed information about the onset of muscle activation during the maneuver of sitting down, and, furthermore, it revealed differences in muscle activation between healthy subjects (controls) and patients with musculoskeletal (locomotor) system involvement (ankylosing spondylitis). Different positions of the lower and upper limbs led to different sequences of muscle activation. Unique or typical patterns of muscle activation were not found in neither of the groups under study.

\section{ACKNOWLEDGEMENT}

The study has been supported by the research grant from the Ministry of Education, Youth and Sports of the Czech Republic (No. MSM 6198959221) "Physical Activity and Inactivity of the Inhabitants of the Czech Republic in the Context of Behavioral Changes".

\section{REFERENCES}

De Luca, C. J. (1993). The use of surface electromyography in biomechanics. The International Society for Biomechanics. Retrieved 7. 5. 2000 from the World Wide Web: http://www.delsys.com/

Ferrante, S., Pedrocchi, A., \& Ferrigno, G. (2005). Electromyographic analysis of standing up and sitting down. In 10th Annual Conference of the International FES Society. Retrieved 20. 5. 2009 from the World Wide Web: http://www.ifess.org/ifess05/Poster\%20 Session\%203/Ferrante\%20S.pdf

Hase, K., Sako, M., Ushiba, J., \& Chino, N. (2004). Motor strategies for initiating downwardoriented movements during standing in adults. Experimental Brain Research, 158, 18-27.

Heinonen, P., Kautiainen, H., \& Mikkelsson, M. (2005). Erector spinae SEMG activity during forward flexion and re-extension in ankylosing spondylitis patients. Pathophysiology, 12(4), 289-293.

Hof, A. L., Elzinga, H., Grimmius, W., \& Halbertsma, J. P. K. (2002). Speed dependence of averaged EMG profiles in walking. Gait and Posture, 16(1), 78-86.

Konrad, P. (2005). The ABC of EMG. Noraxon INC. USA.

Smékal, D., Opavský, J., Urban, J., \& Mayer, M. (2005). Stereotyp vstávání ze sedu v klinické praxi. Rehabilitace a fyzikální lékařství, 12(2), 62-67.
Trew, M., \& Everett, T. (1997). Human movement: An introductory text. New York: Churchill Livingstone.

Véle, F. (1997). Kineziologie pro klinickou praxi. Praha: Grada.

Wai-Hang, J. L. (2004). Are you left handed? Footedness questionnaire. Retrieved 16. 3. 2004 from the World Wide Web: http://jackie.freeshell.org/woh/test_foot. htm

William, W. L., Yong, H., Keith, D. K. L., Kenneth, M. C. Ch., \& John, C. Y. L. (2002). Paraspinal muscle activities of patients with scoliosis after spine fusion. Spine, 27(11), 1180-1185.

\section{POVRCHOVÉ ELEKTROMYOGRAFICKÉ HODNOCENÍ SVALOVÉ AKTIVITY VE ZKOUŠCE POSAZENÍ U ZDRAVÝCH MLADÝCH ŽEN A U PACIENTU゚ S ANKYLOZUJÍCÍ SPONDYLITIDOU}

(Souhrn anglického textu)

VÝCHODISKA: Časové zapojování (aktivace) svalů je závislé na mnoha faktorech. Povrchová polyelektromyografie zachycuje vzorce zapojování svalů u probandů rozdílného věku a zdravotního stavu v různých podmínkách.

CÍLE: Cílem studie byla registrace a hodnocení pořadí zapojování svalů v průběhu sedání u těchto dvou skupin žen ve čtyřech situacích s rozdílnými pozicemi horních i dolních končetin.

METODIKA: Studovali jsme pořadí zapojování svalů u dvou skupin žen - zdravých mladých žen (jako kontrolní skupiny) a pacientů s ankylozující spondylitidou. Aktivace vybraných svalů byla hodnocena povrchovou polyelektromyografií (Noraxon-MyoSystem 1400A). Elektrody byly umístěny nad čtyři vybrané svaly bilaterálně (m. tibialis anterior, mediální hlava $\mathrm{m}$. gastrocnemii, $\mathrm{m}$. gluteus maximus a $\mathrm{mm}$. erectores spinae). Pro zjištění okamžiku nástupu zapojení svalů (timing) jsme použivali klidovou hodnotu amplitudy EMG signálu plus $10 \%$ maximální hodnoty amplitudy (peak).

VÝSLEDKY: V naši studii jsme zjistili, že ve většině sledovaných situací prvním aktivovaným svalem byla mediální hlava $\mathrm{m}$. gastrocnemii nebo $\mathrm{mm}$. erectores spinae. Dále byla zjištěna velká variabilita v pořadí zapojování svalů, která byla závislá na pozici horních a dolních končetin.

ZÁVĚRY: V této studii nebyly prokázány jednotné vzorce pro pořadí zapojování svalů $\mathrm{v}$ prủběhu sedání u obou skupin probandů.

Klícová slova: poly-EMG, sedání, zdravé mladé ženy, ankylozujicí spondylitida. 
Mgr. Amr Mohamed Zaki Zaatar, Ph.D.

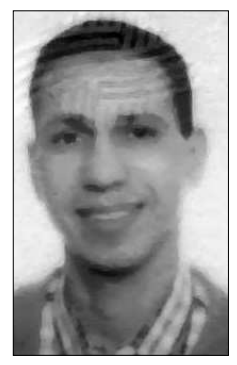

Palacký University, Olomouc

Faculty of Physical Culture

tř. Míru 115

77111 Olomouc

Czech Republic

\section{Education}

2010 - Ph.D. - Faculty of Physical Culture, Palacký University in Olomouc, Czech Republic (title of thesis: Assessment muscle coordination in situations with different postural positions by polyelectromyography). 2002 - Master of physiotherapy - Faculty of Physical Culture, Palacký University in Olomouc, Czech Republic (title of thesis: Relationship between gait asymmetry and test of laterality).
1998 - Bachelor of physiotherapy - Faculty of Medicine (physiotherapy), Palacký University in Olomouc, Czech Republic.

\section{Previous work experience}

2010 - assistant professor with Ph.D. in department of physiotherapy, Faculty of Physical Culture, Palacký University in Olomouc, Czech Republic.

2009 - assistant professor without Ph.D. in department of physiotherapy, Faculty of Physical Culturem, Palacký University in Olomouc, Czech Republic.

2006 - assistant in department of physiotherapy, Faculty of Physical Culture, Palacký University in Olomouc, Czech Republic.

2005 - specialist in surface electromyography, Faculty of Physical Culture, Palacký University in Olomouc, Czech Republic.

Since 2002 - rehabilitation center (R. R. R.), Faculty of Physical Culture, Palacký University in Olomouc, Czech Republic. 